\begin{tabular}{|l|l|l||}
\hline \multicolumn{2}{|c|}{ PublisherInfo } \\
\hline \hline PublisherName & $:$ & BioMed Central \\
\hline \hline PublisherLocation & $:$ & London \\
\hline \hline PublisherImprintName & $:$ & BioMed Central \\
\hline \hline
\end{tabular}

\title{
Matrix metalloproteinases and angiogenesis
}

\begin{tabular}{|l|l|l||}
\hline \multicolumn{2}{|c|}{ ArticleInfo } \\
\hline \hline ArticleID & $:$ & 3739 \\
\hline \hline ArticleDOI & $:$ & $10.1186 /$ bcr-2000-66702 \\
\hline \hline ArticleCitationID & $:$ & 66702 \\
\hline \hline ArticleSequenceNumber & $:$ & 105 \\
\hline \hline ArticleCategory & $:$ & Paper Report \\
\hline ArticleFirstPage & $:$ & 1 \\
\hline \hline ArticleLastPage & $:$ & 4 \\
\hline \hline & & RegistrationDate : 2000-11-7 \\
\hline ArticleHistory & $:$ & OnlineDate \\
\hline \hline ArticleCopyright & $:$ & Current Science Ltd2000-11-7 \\
\hline \hline ArticleGrants & $:$ & \\
\hline \hline ArticleContext & $:$ & 1305822 \\
\hline \hline
\end{tabular}


Valerie Speirs, ${ }^{\text {Aff1 }}$

Aff1 Molecular Medicine Unit, University of Leeds, UK

\section{Keywords}

Angiogenesis, MMPs, VEGF

\section{Introduction}

Once a tumour reaches a critical size, for further expansion to take place, it must develop a blood supply: this process is known as angiogenesis. The switch to an angiogenic phenotype involves the recruitment of capillary endothelial cells which respond to proangiogenic factors and produce new blood vessels. One such factor is VEGF. However, during islet cell carcinogenesis, rather than being upregulated in tumours, VEGF is produced constitutively in both transformed and non-transformed pancreatic islets. This is also true for VEGF receptors, flt-1 (VEGF-R1) and flk-1 (VEGF-R2). Therefore this implies that there must be one or more additional regulatory events which induce angiogenesis in the development of a transformed phenotype.

\section{Aims}

To determine the factors that control the switch from vascular quiescence to an angiogenic phenotype during islet cell carcinogenesis.

\section{Comments}

Angiogenesis is essential for tumours to grow beyond a few millimetres. The identification of angiogenic factors and the pathways through which they act is essential in our understanding of the process, and aids the identification of possible targets for therapy. Although based on islet cell carcinogenesis, the mouse model described in this paper has revealed important new information about two previously identified factors involved in angiogenesis, namely vascular endothelial growth factor (VEGF) and matrix metalloproteinase (MMP)-9. VEGF, in particular, is already an independent prognostic factor in breast cancer, and understanding how it is regulated is essential. Ultimately this should help to better define and treat not only breast cancer but other types of cancer as well. 


\section{Methods}

The RIP1-Tag2 transgenic mouse model (see Additional information) was used, in which every mouse develops islet cell tumours of the pancreas by 12-14 weeks. Normal pancreases and those from RIP1-Tag2 mice were removed and processed for immunohistochemical analysis of VEGF, VEGF receptors -1 and -2, the complete VEGF-VEGF-R complex or MMP-9. Apoptotic cells were determined by TUNEL and proliferating cells by PCNA staining. Soluble pancreatic extracts were analysed by gelatin zymography for MMP-2 and -9. Culture media was retained for analysis of VEGF by ELISA. To assess both the frequency of angiogenic switching and end stage tumour load, animals were treated with SU5416, a synthetic anti-angiogenic agent which inhibits VEGF-R2-mediated signal transduction.

\section{Results}

Treatment with the SU5416 prevented activation of the angiogenic switch in 94\% of hyperplastic islets and reduced tumour growth by $75 \%$. Immunohistochemical analysis showed universal expression of VEGF and its receptors, although the VEGF-VEGF-R2 complex was only detected in angiogenic islets and in tumours. Angiogenic islets cocultured with endothelial cells showed endothelial sprouting: this was not observed in nonangiogenic islets and furthermore could be blocked by a VEGF neutralising antibody, supporting a role for VEGF in the angiogenic process.

There was an upregulation of both MMP-2 and MMP-9 in association with the angiogenic switch. In vitrotreatment of normal islets cocultured with endothelial cells with MMP-9, but not MMP-2, trypsin, urokinase or collagenase $\mathrm{P}$, resulted in an angiogenic phenotype. This could be blocked by the MMPinhibitor, GM6001. Levels of VEGF released into the medium, as determined by ELISA, were approximately twofold higher after MMP-9 treatment and could be blocked by GM6001. MMP-9 was not expressed in normal non-transgenic islets, but rather by a small number of cells in close apposition to the vasculature. MMP-9 was also found in the basement membrane of tumours. A comparative pharmacological (using MMP inhibitors) and genetic (using knockouts) approach showed MMP inhibitors reduced angiogenic switching, tumour number and growth, as did genetic ablation of MMP-9. By contrast, absence of MMP-2 was ineffective in angiogenesis induction but did slow tumour growth.In MMP-9 knockouts and those treated with SU5416, rates of cell proliferation were reduced to similar effects, with a concomitant rise in the apoptotic index.

\section{Discussion}

MMP-9 is a functional component of the angiogenic switch during islet cell carcinogenesis. Its likely mode of action is to increase the availablity of the pro-angiogenic factor, VEGF. Inhibitors of these 
agents may be effective in combination as targets to prevent the angiogenic switch or to retard angiogenesis during the process of carcinogenesis.

\section{Additional information}

Hanahan D: Heritable formation of pancreatic B cell tumours in transgenic mice harbouring recombinant insulin/simian virus-40 oncogenes. Nature 1985, 315:115-122(PubMed\%20abstract)

\section{References}

1. Bergers G, Brekken R, McMahon G, Vu TH, Itoh T, Tamaki K, Tanzawa K, Thorpe P, Itohara S, Werb Z, Hanahan D: Matrix metalloproteinase-9 triggers the angiogenic switch during carcinogenesis. Nat Cell Biol. 2000, 2: 737-744.

This PDF file was created after publication. 